\title{
Low smokeless tobacco tax contributes to smokeless epidemic
}

The remarkably low level of cigarette taxation in the US is well-documented and has been the subject of much attention in recent years. ${ }^{1}$ What is less well known is that the US federal government taxes smokeless tobacco products at about one-tenth the rate of cigarettes (see figure). Indeed, at 2.7 cents per tin of moist snuff and 2.3 cents per pouch of chewing tobacco, smokeless tobacco is virtually untaxed at the federal level. Taxation by the states is uneven. Sixteen impose no smokeless tax at all; of the 34 that do impose a tax, 26 impose smokeless taxes that are within $10 \%$ of the rate imposed on cigarettes. ${ }^{2}$

This low level of taxation, combined with aggressive youth-oriented marketing by the smokeless tobacco industry, has created what the US Department of Health and Human Services has called "an impending oral cancer epidemic". ${ }^{3}$ At a time when use of all other tobacco products is declining, moist snuff sales grew $47 \%$ between 1986 and $1990{ }^{4}$ The smokeless tobacco industry continues to deny that its products cause cancer and are addictive, despite research showing that long-term snuff users are almost 50 times more likely to develop cancers of the gum and buccal mucosa (the tissues that come into direct contact with the tobacco), ${ }^{5}$ and that the typical dose of snuff contains two to three times more nicotine than a single cigarette. ${ }^{3}$

Because smokeless tobacco users are disproportionately young and economically disadvantaged, it is not surprising that they would be especially sensitive to tax increases, as suggested by new data reported by Ohsfeldt and Boyle in this issue of Tobacco Control. ${ }^{6}$ Documenting the correlation between smokeless tax rates and consumption is an important step forward in policy research, and will assist efforts to raise smokeless taxes at all levels of government in the US and around the world. As the authors themselves are quick to point out, however, their ecological research is an initial step. Additional research is necessary to accurately measure price, income, and tax elasticities of demand for smokeless products.

An equally important finding by Ohsfeldt and Boyle is that higher cigarette taxes are associated with higher smokeless tobacco usage. This, too, is not surprising, given that smokeless tobacco and cigarette manufacturers are competitors in the market for nicotine. ${ }^{\star}$ If the price of one nicotine product goes up, some users are bound to switch to an alternative source. The authors have performed a valuable service by providing data to reinforce economic theory. Their work provides a powerful reminder that tobacco taxes should be imposed on an equivalent basis on all tobacco products.

During the past year, the smokeless tobacco industry in the US lobbied aggressively to maintain its low tax rates and its huge tax advantage over cigarettes during the vigorous debate over how high to raise tobacco taxes to help pay for various health care reform proposals. The debate was left unresolved, for now, when Congress adjourned in 1994 without passing any health care reform proposal. The smokeless tobacco industry's chief arguments against a significant tax increase were that raising

\footnotetext{
* See figures on pp 306-7. - ED
}

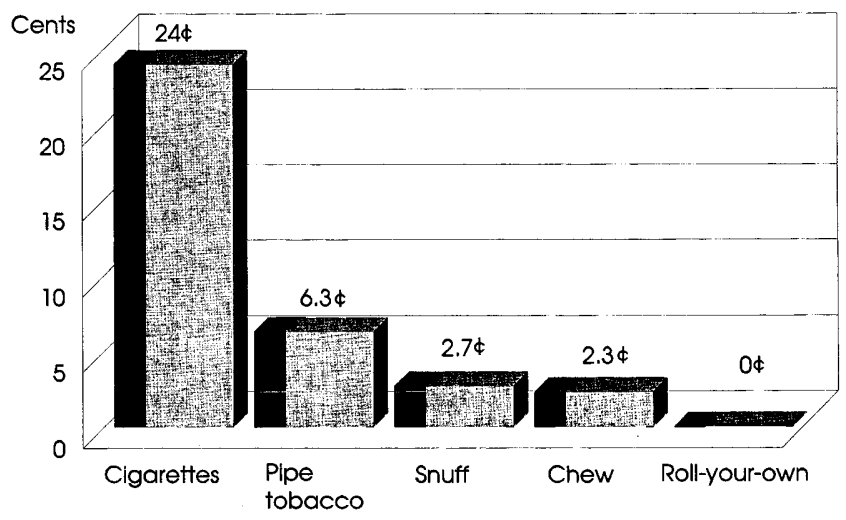

Figure Current federal tax on tobacco products in the US per retail unit

and equalizing tax rates on all tobacco products would require a huge increase when expressed in percentage terms, and that such a large tax would put some smokeless companies out of business.

The large percentage increase, of course, is the result of measuring from a starting point close to zero. The argument that smokeless tobacco companies would go out of business if taxes are raised and equalised with those applied to cigarettes also is deceptive. UST, the giant multinational corporation that commands $87 \%$ of the US snuff market, certainly would not be endangered. UST was the single most profitable company on the New York Stock Exchange in 1993, with profits of more than 50 cents for every dollar of revenue. ${ }^{?}$

The message to policy makers and advocates should be loud and clear: smokeless tobacco is not a safe alternative to smoking and deserves no special treatment. Cigarette taxes should be raised substantially and smokeless tobacco taxes should be set at an equivalent rate. To tax smokeless tobacco at a lower rate would continue to encourage smokeless tobacco use and would continue to provide an economic windfall to companies that market a deadly and addictive product.

JOHN BLOOM MICHAEL BIRNBAUM

American Cancer Society,

316 Pennsylvania Avenue, SE, Suite 200, Washington, DC 20003, USA

1 Sweanor D. Time for a change in US tobacco tax policy. Tobacco Control 1993; 2 : 1-2.

2 Connolly GN. Testimony on the Health Security Act, before the Committee on Ways and Means, US House of Representatives, 18 November 1993.

3 US Department of Health and Human Services. Spit tobacco and youth. Washington, DC: Office of Inspector General, 1992: 6. (DHHS Publication No (OEI) 06-92-00500.)

4 US Department of Health and Human Services. Smokeless tobacco or health: an international perspective. Rockville, Maryland: National Cancer Institute, 1992: iv. (NIH Publication No 92-3461.)

5 Winn DM, Blot WJ, Shy CM, Pickle LW, Toledo A, Fraumeni JF. Snuff dipping and oral cancer among women in the southern United States. $N$ Engl $\mathcal{f}$ Med $1981 ; 304: 745-9$.

6 Ohsfeldt RL, Boyle R. Tobacco excise taxes and rates of smokeless tobacco use in the United States: an exploratory ecological analysis. Tobacco Control 1994; 3 : 316-23.

7 Just a pinch can be very dangerous and profitable. Washington Post 14 January 1994: B1. 